\title{
In vitro EVALUATION OF EUCALYPTUS ECTOMYCORRHIZAE ON SUBSTRATE WITH PHOSPHORUS DOSES FOR FUNGAL PRE-SELECTION ${ }^{1}$
}

\author{
Lidiomar Soares Costa ${ }^{2}$, Paulo Henrique Grazziotti ${ }^{3}$, Danielle Cristina Fonseca Santos Grazziotti ${ }^{4}$, \\ Alexandre Christófaro Silva ${ }^{3}$, Márcio José Rossi ${ }^{5}$, Enilson de Barros Silva ${ }^{6}$, Victor Hugo Duarte da \\ $\mathrm{Costa}^{4}$ e Ângela Laís Fernandes Gomes ${ }^{4}$
}

\begin{abstract}
The benefit promoted by ectomycorrhizal depends on the interaction between symbionts and phosphorus (P) contents. Phosphorus effect on ectomycorrhizal formation and the effectiveness of these in promoting plant growth for fungal pre-selection were assessed under in vitro conditions. For P effect evaluation, Eucalyptus urophylla seedlings inoculated with four Pisolithus sp. isolates and others non-inoculated were grown on substrate containing $0.87,1.16$ and $1.72 \mathrm{mg}$ P per plant. For evaluation of effectiveness and fungal pre-selection, other 30 isolates of Pisolithus sp., Pisolithus microcarpus ITA06 isolate, Amanita muscaria AM16 isolate, Scleroderma areolatum SC129 isolate were studied. D26 isolate promoted the highest plant heights for the three P doses, D51 at the lower dose and D72 at the intermediate dose. P doses did not influenced shoot fresh weight and fungal colonization. In the pre-selection of fungi, 14 isolates of Pisolithus sp., P. microcarpus ITA06 isolate and S. areolatum SC129isolate increased plant height and fresh weight. D82 isolate of Pisolithus sp. had effect singly on plant height while D17 and D58 on fresh weight. Of these, only D15, D17, D58 and ITA06 had typical ectomycorrhizae. The cultivation in vitro has shown adequate for pre-selection of ectomycorrhizal fungi. Colonization and benefits depend on species and isolate. D15, D17 and D58 of Pisolithus sp. and P. microcarpus isolate ITA06 are the most promising for nursery studies.
\end{abstract}

Keywords: Inoculation; Ectomycorrhizal fungi; Controlled mycorrhization.

\section{AVALIAÇÃO in vitro DE ECTONICORRIZAS EM EUCALIPTO UTILIZANDO SUBSTRATO COM DOSES DE FÓSFORO PARA PRÉ-SELEÇÃO DE FUNGOS}

\begin{abstract}
RESUMO - O benefício promovido pelas ectomicorrizas é dependente da interação entre os simbiontes e dos teores de fósforo $(P)$. O efeito do $P$ na formação de ectomicorrizas e a efetividade destas na promoção do crescimento das plantas para pré-seleção de fungos foram estudadas in vitro. Para avaliação do efeito do P, plântulas de Eucalyptus urophylla inoculadas com quatro isolados de Pisolithus sp. e não-inoculadas foram crescidas em substrato com 0,87, 1,16 e 1,72 mg de P por planta. Para avaliação da efetividade e pré-seleção de fungos, outros 30 isolados de Pisolithus sp., Pisolithus microcarpus isolado ITA06, Amanita muscaria isolado AM16, Scleroderma areolatum isolado SC129 foram estudados. O isolado D26 promoveu
\end{abstract}

\footnotetext{
${ }^{1}$ Recebido em 23.01.2014 aceito para publicação em 22.09.2014

${ }^{2}$ Universidade Federal dos Vales do Jequitinhonha e Mucuri, Graduado em Engenharia Florestal, Diamantina, MG - Brasil. E-mail: <lidiomar.ef@bol.com.br>.

${ }^{3}$ Universidade Federal dos Vales do Jequitinhonha e Mucuri, Faculdade de Ciências Agrárias, Departamento de Engenharia Florestal, Diamantina, MG - Brasil. E-mail: <grazziot@yahoo.com.br>e < alexandre.christo@ufvjm.edu.br>.

${ }^{4}$ Universidade Federal dos Vales do Jequitinhonha e Mucuri, Programa de Pós-Graduação em Produção Vegetal, Diamantina, MG - Brasil. E-mail: <daniagronomia@yahoo.com.br>, <victorhugodc@yahoo.com.br>e<lah492@gmail.com>.

${ }^{5}$ Universidade Federal de Santa Catarina, Departamento de Microbiologia e Parasitologia, Campus Universitário Trindade, Florianopolis, SC - Brasil. Email: <marcio@enq.ufsc.br>.

${ }^{6}$ Universidade Federal dos Vales do Jequitinhonha e Mucuri, Faculdade de Ciências Agrárias, Departamento de Agronomia, Diamantina, MG - Brasil. E-mail: <ebsilva@ufvjm.edu.br>.
}

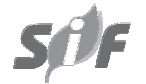

Revista Árvore, Viçosa-MG, v.39, n.1, p.127-136, 2015 http://dx.doi.org/10.1590/0100-67622015000100012 
a maior altura das plantas nas três doses de P, o D51 na menor dose e o D72 na dose intermediária. As doses de P não influenciaram a massa fresca da parte aérea e a colonização. Na pré-seleção de fungos, 14 isolados de Pisolithus sp., P. microcarpus isolado ITA06 e S. areolatum isolado SC129 aumentaram a altura e a massa fresca das plantas (MFP). O isolado D82 de Pisolithus sp. aumentou somente a altura e o D17 e D58 aumentaram somente a MFP. Destes, somente para o D15, D17, D58 e ITA06 observou-se ectomicorrizas típicas. O cultivo in vitro demonstrou-se adequado para a pré-seleção de fungos ectomicorrízicos. A colonização e os benefícios são dependentes da espécie e também do isolado fúngico. Os isolados D15, D17 e D58 de Pisolithus sp. e P. microcarpus isolado ITA06 são os mais promissores para estudos em viveiros.

Palavras-chave: Inoculação; Fungos ectomicorrízicos; Micorrização controlada.

\section{INTRODUCTION}

Ectomycorrhizal fungal (EMF) can act with variable efficiency on plant growth, especially those belonging to Eucalyptus genus (SAWYER et al., 2003). Generally, during ectomycorrhizal formation, roots undergo through profound morphological and physiological changes, starting to act in an integrated and congruous manner with the fungus, with gains in adaptability and survival of these symbionts (BARKER et al., 1998).

Ectomycorrhizal fungi can provide the host plant increased tolerance to toxic substances in soil (GRAZZIOTTI et al., 2003), resistance to water stress, extreme values of temperature and soil acidity (POZO; AZCON-AGUILAR, 2007) and pathogens of root system (BAUMERT et al., 1997). Yet the main effect is the increase of root absorption surface, allowing better use of water and nutrients such as N, K and especially $\mathrm{P}$, which is less mobile in soil (BOUGHER et al., 1990; SAWYER et al., 2003).

Overall, these benefits obtained under ectomycorrhizal association are variable and dependent on soluble $\mathrm{P}$ availability in soil, which in large amounts can limit association and its scarcity affects plant growth and yield. When P is extremely limited, growth of both symbionts is impared (DIGTHON et al., 1993). Low $\mathrm{P}$ availability in soil increases host growth by fungal action. In addition, higher $\mathrm{P}$ levels promote fungus growth to the detriment of plant (BOUGHER et al., 1990). Although low symbiotic efficiency, high P content did not fully prevent root colonization (QUORESHI; KHASA, 2008); however, most symbiotic efficiency between Eucalyptus and EMF isolates occurs in sub-optimal P levels (SOARES et al., 1990; SOUZA et al, 2004). For Eucalyptus dunnii seedlings inoculated with four EMF and grown in fertilized substrates with 0 to $8 \mathrm{mg}$ P per plant, the doses above $4 \mathrm{mg}$ per plant completely inhibited EMF colonization for three isolates (SOUZA et al., 2004).

Studies of ectomycorrhizal formation in laboratory have helped in understanding this process, since each association-forming stage is highly regulated by molecular interactions that result in morphological and physiological alterations in both organisms (BARKER et al., 1998). In vitro assays for different fungus and plant species, which are able to establish ectomycorrhizal association, is essential for controlled mycorrhization process. Mycorrhization control is based on inoculation of soil specific fungi into plants, taking as basis the mutualistic relationship between these organisms (GARBAYE, 1990). This process begins with the selection of the most effective fungal isolates and involves the test of ectomycorrhizal isolate ability to form this symbiosis, which can be performed by in vitro synthesis.

In this way, the target points of this study were to evaluate the effect of $\mathrm{P}$ concentrations on ectomycorrhizal formation, then use assessment of mycorrhizal effectiveness and the promotion of plant growth in vitro for pre-selection of ectomycorrhizal isolate obtained from commercial eucalypts plantations.

\section{MATERIALS AND METHODS}

\subsection{Ectomycorrhizal synthesis in vitro in substrate with P doses}

\subsubsection{Experimental design}

The experiment was carried out in an entirely randomized design in a $5 \times 3$ factorial scheme, using D3, D26, D51 and D72 isolates of Pisolithus sp., plus one non-inoculated (control) and $\mathrm{P}$ dosed of $0.87,1.16$ and $1.72 \mathrm{mg} \mathrm{plant}^{-1}$. The supplied phosphorus amounts were obtained from dibasic potassium phosphate $\left(\mathrm{KH}_{2} \mathrm{PO}_{4}\right)$ reduction of Melin-Norkrans modified culture medium 
(MNM) (MARX, 1969) added into the substrate used for Eucalyptus urophylla seedling growth.

\subsubsection{Experiment assembling and conduction}

The Pisolithus sp. used isolates were obtained from EMF collection of the Laboratory of Soil Microbiology - UFVJM. Pure isolate cultures were originally obtained from basidiomas sampled in Eucalyptus spp. plantations in Vale do Jequitinhonha - Minas Gerais, which had already known effectiveness with this plant by preliminary assays. Each fungal inoculum was obtained from isolate transferring to solid MNM culture medium (MARX, 1969) and incubated for 20 days at $25^{\circ} \mathrm{C}$.

Eucalyptus urophylla ST Blake seedlings from surface-disinfected seeds were treated by placing them on a sieve and washing three times with a $50 \%$ alcohol solution, rinsing with sterile distilled water, and immersing in a $0.5 \%$ sodium hypochlorite solution for one minute and again rinsed three times in sterile distilled water. After this treatment, they were sown into Petri dishes $(\varnothing=100 \mathrm{~mm})$ containing three sterile germination paper moistened with sterile distilled water. The entire process was carried out under aseptic conditions in a laminar flow cabinet. The seeds were incubated for two weeks at $25^{\circ} \mathrm{C}$ and 12 -hour photoperiod. During this period, sterile distilled water was added to maintain moisture level.

Test tubes of $20-\mathrm{cm}$ height and $2.5 \mathrm{~cm}$ diameter were coated internally with germination paper from base up to $11.4 \mathrm{~cm}$ high, and added $56-\mathrm{cm}^{3}$ peat: vermiculite $\operatorname{mix}(1: 20, \mathrm{v} / \mathrm{v})$ and $10-\mathrm{ml}$ distilled water. Then, the tubes were closed with two layers of cellophane tape and sterilized twice for 20 minutes at $121^{\circ} \mathrm{C}$. After cooling, we added $10 \mathrm{~mL}$ MNM liquid medium at $\mathrm{pH}$ 5.3 , and the tubes were sterilized again afterwards.

Two-week after sowing, E. urophylla seedlings had total height between 0.8 and $1 \mathrm{~cm}$, and they were transferred to the test tubes. Each tube has received one seedling, placing roots between germination paper and the tube wall, so it was possible to visualize them periodically. The tubes were wrapped in foil covering in all substrate area and subsequently incubated for two days at $25^{\circ} \mathrm{C}$ and 12 -hour photoperiod in a BOD oven, until the inoculation.

For inoculation of fungal isolates into plants, we used 5-mm diameter culture medium discs, mycelium detached from borders of isolate colonies with 20-day growth on solid MNM medium. These discs were placed on MNM solid medium within Petri dishes to reactivate the mycelium damaged by cuts and check absence of contamination. After two days, the viable discs were used for plant inoculations by placing one disc on either side of the roots, also between the germination paper and tube wall. The non-inoculated (control) one was prepared by using the same disc medium without mycelium. The tubes were again placed in the growth chamber where they remained for 40 days at $25^{\circ} \mathrm{C}$ and 12-hour photoperiod.

\subsubsection{Evaluations and statistical analysis}

Plant height was measured at 10,20,30 and 40 days after being transferred to the tubes. Additionally, at 40 days, the plant shoot was removed at root collar region and weighed to determine shoot fresh weight (SFW). Roots were immersed in water and washed with squeeze bottle to facilitate its separation from substrate. Then, the root system of each plant was fixed in FAA (100 ml alcohol, $100 \mathrm{ml}$ distilled water, $13 \mathrm{ml}$ formalin and $5 \mathrm{ml}$ acetic acid) solution, which was used to determine the percentage of root tips colonized by direct counting in stereomicroscope with 30x magnification (BRUNDRET et al., 1996).

For microscopic characterization, mycorrhizae were cut into 20 to $30-\mu \mathrm{m}$-thick sections using a microtome and placed on glass slides for microscopy. Next, they were mounted in a mixture containing a drop of polyvinyl alcohol-lacto-glycerol (16.6 g of polyvinyl alcohol + $100 \mathrm{ml}$ of distilled water $+100 \mathrm{ml}$ lactic acid $+10 \mathrm{ml}$ glycerin) and one drop of cotton blue solution $(0.05 \%)$ in lacto-glycerol $(0.04 \mathrm{~g}$ methylene blue $+10 \mathrm{ml}$ lactic acid $+20 \mathrm{ml}$ glycerin $+10 \mathrm{ml}$ distilled water). Subsequently, they were visualized under the microscope at 400x to $1,000 x$, sections were photographed and classified as follows: (-) no colonization, $(+)$ with fungal mantle colonization, $(++)$ with Hartig net and fungal mantle, $(+++)$ with Hartig net and thick fungal mantle according to Figure 1.

The statistical analysis was performed by analysis of variance, and for the plant height, it was considered as a source of variation growth times after inoculation $(10,20,30$ and 40 days), $P$ doses and isolates. Thus, for this variable, it was analyzed: the triple factorial $5 \times 3 \times 4$ referring to isolates, doses, time after inoculation, respectively. When significant for height, isolate effect

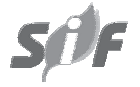

Revista Árvore, Viçosa-MG, v.39, n.1, p.127-136, 2015 


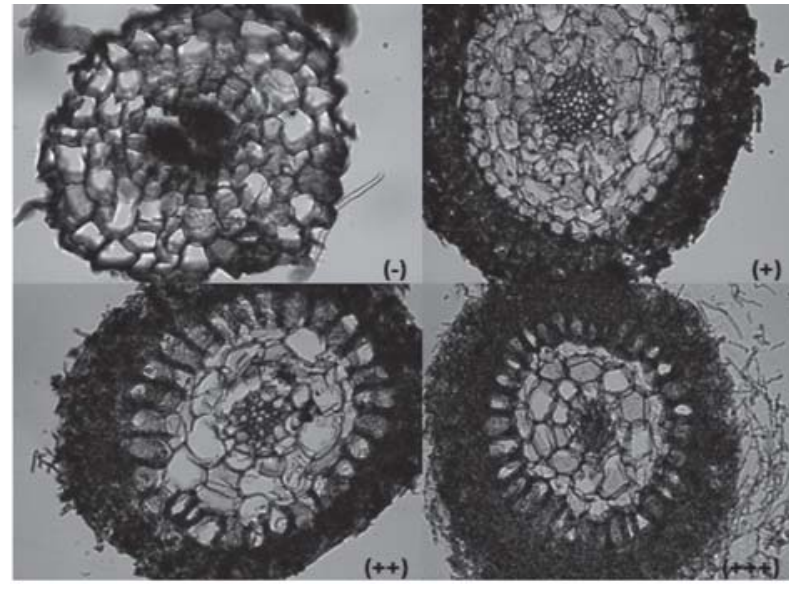

Figure 1 - Grades awarded for ectomycorrhizal colonization on plants of Eucalyptus urophylla: (-) without colonization, $(+)$ with fungal mantle, $(++)$ with Hartig net and fungal mantle $(+++)$ with Hartig net and thick fungal mantle.

Figura 1 - Notas atribuídas para colonização ectomicorrízica em plantas de Eucalyptus urophylla. (-) sem colonização, $(+)$ com manto fúngico, $(++)$ com rede de Hartig e manto fúngico, $(+++)$ com rede de Hartig e manto fúngico espesso.

was compared by regression equations. Means of SFW and percentage of root tip colonization were compared by Tukey test at 5\% probability.

\subsection{In vitro selection of ectomycorrhizal fungi}

\subsubsection{Experimental design}

The experiment was arranged in a totally randomized design. The treatments were the isolates D1, D4, D5, D6, D7, D10, D12, D13, D14, D15, D17, D20, D23, D26, D27, D29, D46, D50, D52, D57, D58, D61, D63, D70, D76, D77, D81, D82, UFVJM4, and UFVJM5 of Pisolithus sp.; ITA06 of Pisolithus microcarpus; AM16 of Amanita muscaria; SC129 of Scleroderma areolatum, a noninoculated one, with five replications and experimental plots composed by one plant. The Pisolithus sp. isolates were obtained from basidiomas sampled from commercial Eucalyptus sp. plantations in Jequitinhonha Valley in Minas Gerais State, Brazil, which had been donated by the Laboratory of Soil Microbiology of the UFVJM. The $P$. microcarpus, A. muscaria and S. areolatum fungi were isolated from commercial Eucalyptus sp. plantations in Santa Catarina State and had been donated by the Department of Microbiology, Immunology and Parasitology of the Federal University of Santa Catarina.

\subsubsection{Experiment assembling and conduction}

The experiment assembling and conduction were performed as described above for earlier essay; however, by using only $1.72 \mathrm{mg} \mathrm{P}$ dose per plant. This dose has been chosen due to its great previous performance for isolate effectiveness to colonize roots and has promoted height increase.

\subsubsection{Evaluation and statistical analysis}

Forty days after seedlings transfer into tubes, it was evaluated height, plant fresh weight ( $\underline{\text { PFW) }}$ and percentage colonized root tips. Newly, ectomycorrhizal were characterized for presence or absence of fungal mantle and Hartig net as described formerly.

Data statistical analysis was performed by variance analysis and, when significant, means were compared by Scott Knott test at 5\% probability.

\section{RESULTS}

\subsection{In vitro synthesis of ectomycorrhizal fungi in substrate with $\mathbf{P}$ doses}

Plant height has increased differently $(\mathrm{p} \mathrm{d} \leq 0.01)$ between Pisolithus sp. isolates and P doses (Figure 2). In general, height growth ceased after 30 days of inoculation, what was more pronounced at the highest P dose. Plants inoculated with D3, D26, and D72 isolates at the lowest $\mathrm{P}$ dose and for non-inoculated at the intermediate dose $\left(1.16 \mathrm{~g} \mathrm{plant}^{-1} \mathrm{P}\right)$, the plant height increased linearly up to the $40^{\text {th }}$ day.

At the lowest $\mathrm{P}$ dose $\left(0.87 \mathrm{mg}\right.$ plant $\left.^{-1} \mathrm{P}\right)$, plant height has also increased linearly for plants inoculated with isolates D3, D26 and D72 and quadratically for plants inoculated with D51 and non-inoculated (Figure 2a). In the latter, growth stabilized at the $30^{\text {th }}$ day (Figure $2 \mathrm{a}$ ). At 40 days, D26 and D51 inoculated plants were on average $23.6 \%$ higher than non-inoculated, while those inoculated with D3 and D72 were always lower than non-inoculated.

At the dose of $1.16 \mathrm{mg} \mathrm{plant}^{-1}$, height of plants inoculated with all isolates showed a quadratic behavior reducing its increase after 30 days (Figure 2b). While non-inoculated plants had a linear behavior. The heights of plants inoculated with D26 and D72 were always higher than non-inoculated with a difference of $34.6 \%$ at 30 days for plants inoculated with D26. Those inoculated with D51 were always lower, and D3 inoculated

Revista Árvore, Viçosa-MG, v.39, n.1, p.127-136, 2015

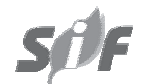




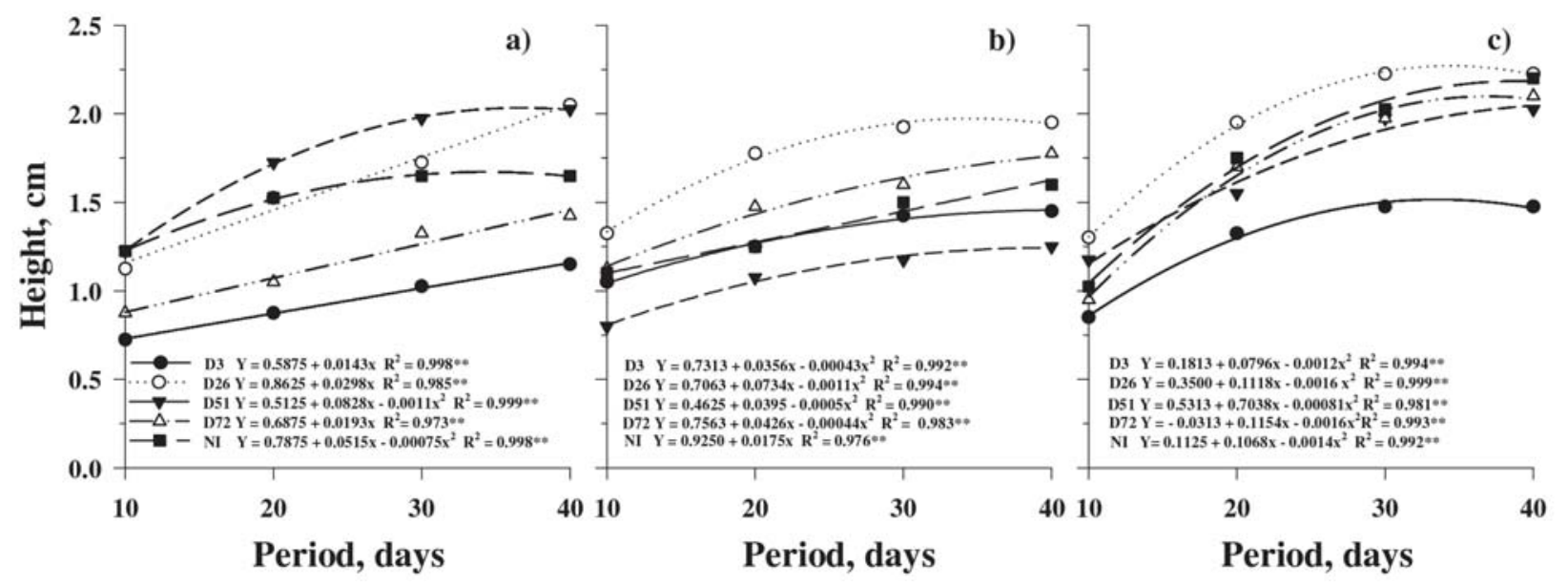

Figure 2 - Height of Eucalyptus urophylla inoculated with isolates D3, D26, D51, D72 of Pisolithus sp. and non-inoculated (NI), grown in a mixture of peat/vermiculite added the following P doses: a) $0.87 \mathrm{mg} \mathrm{plant}^{-1}$, b) $1.16 \mathrm{mg} \mathrm{plant}^{-1}$ and c) $1.72 \mathrm{mg} \mathrm{plant}^{-1}$.** Significant at $1 \%$.

Figura 2 - Altura das plantas de Eucalyptus urophylla inoculadas com os isolados D3, D26, D51, D72 de Pisolithus sp. e não-inoculadas (NI), crescidas em uma mistura de turfa/vermiculita adicionada das seguintes doses de P: (a) 0,87 mg planta ${ }^{-1}$; (b) 1,16 mg planta ${ }^{-1}$ e (c) 1,72 $\mathrm{mg} \mathrm{planta}^{-1}$. ** significativo a 1\%.

plants were smaller than non-inoculated only at the end of the evaluation period (Figure $2 b$ ).

For the highest $\mathrm{P}$ dose $\left(1.72 \mathrm{mg}\right.$ plant $\left.^{-1}\right)$, only D26 increased plant height compared to non-inoculated plants; however, at 40 days, this effect was not seen anymore. At 30 days, D26 inoculated plants were $7.7 \%$ higher than non-inoculated ones. Moreover, the D3 inoculated plants were, at the end of 40 days, $32.8 \%$ lower than non-inoculated ones (Figure 2c). Plant height increased quadratically, both the inoculated as noninoculated plants, and from 30 days on, the plants presented reduced growth rate (Figure c). Height increase by inoculating D26, D51 and D72 isolates, in relation to non-inoculated plants, reduced at the highest $\mathrm{P}$ dose.

SFW and the percentage of colonized root tips were influenced by inoculation of Pisolithus sp. isolates and not by P doses $(\mathrm{p} \leq 0.05)$ (Figure $3 a, b)$. SFW mean of plants inoculated with D26 and D72 was 1.4 times higher than those inoculated with D3, but all were equal to D51 inoculated and non-inoculated ones (Figure 3a).

All isolates formed typical ectomycorrhizae, with Hartig net and fungal mantle (++ or +++$)$, on E. urophylla roots at the three evaluated $\mathrm{P}$ doses. At the lowest dose, ectomycorrhizae formed by D51 and D72 had Hartig net and thick fungal mantle (+++) and, at the other doses, only those formed by D51 remained this standard. The percentage of colonized root tips was similar in inoculated plants, with an average of $51.9 \%$, and absent in non-inoculated ones (Figure 3b).

\subsection{In vitro pre-selection of ectomycorrhizal fungi}

E. urophylla seedling height, plant fresh weight and colonized root tip percentage were related to species and fungal isolate $(\mathrm{p} \leq 0.01)$ (Figure 4$)$. Sixteen out of 33 studied isolates had height and PFW increased compared to non-inoculated plants (D4, D5, D6, D10, D12, D13, D14, D15, D20, D23, D27, D46, D52, D61 of Pisolithus sp., ITA06 of P. Microcarpus and SC129 of S. areolatum) (Figure 4a, b). Besides these, D82 of Pisolithus sp. raised only plant height, plus D17 and D58 had effect on PFW singly.

In descending order, EMF promoted greater percentage of colonized root tips being $\mathrm{D} 63=\mathrm{D} 77=$ $\mathrm{D} 70=\mathrm{D} 81>\mathrm{D} 26=\mathrm{UFVJM} 4=\mathrm{D} 58=\mathrm{D} 17=\mathrm{D} 50=\mathrm{UFVJM} 5$ $=\mathrm{D} 7=\mathrm{D} 27=\mathrm{D} 20>\mathrm{ITA} 06=\mathrm{D} 52=\mathrm{D} 15=\mathrm{D} 12=\mathrm{SC} 129$ $=$ to the others in which colonization was not observed (Figure 4c).

Thirteen of the $18 \mathrm{EMF}$, in which colonization was observed (D7, D15, D17, D26, D50, D58, D63, D70, D77, D81, ITA06, UFVJM4 and UFVJM5) showed typical ectomycorrhizae with Hartig net and fungal mantle, 


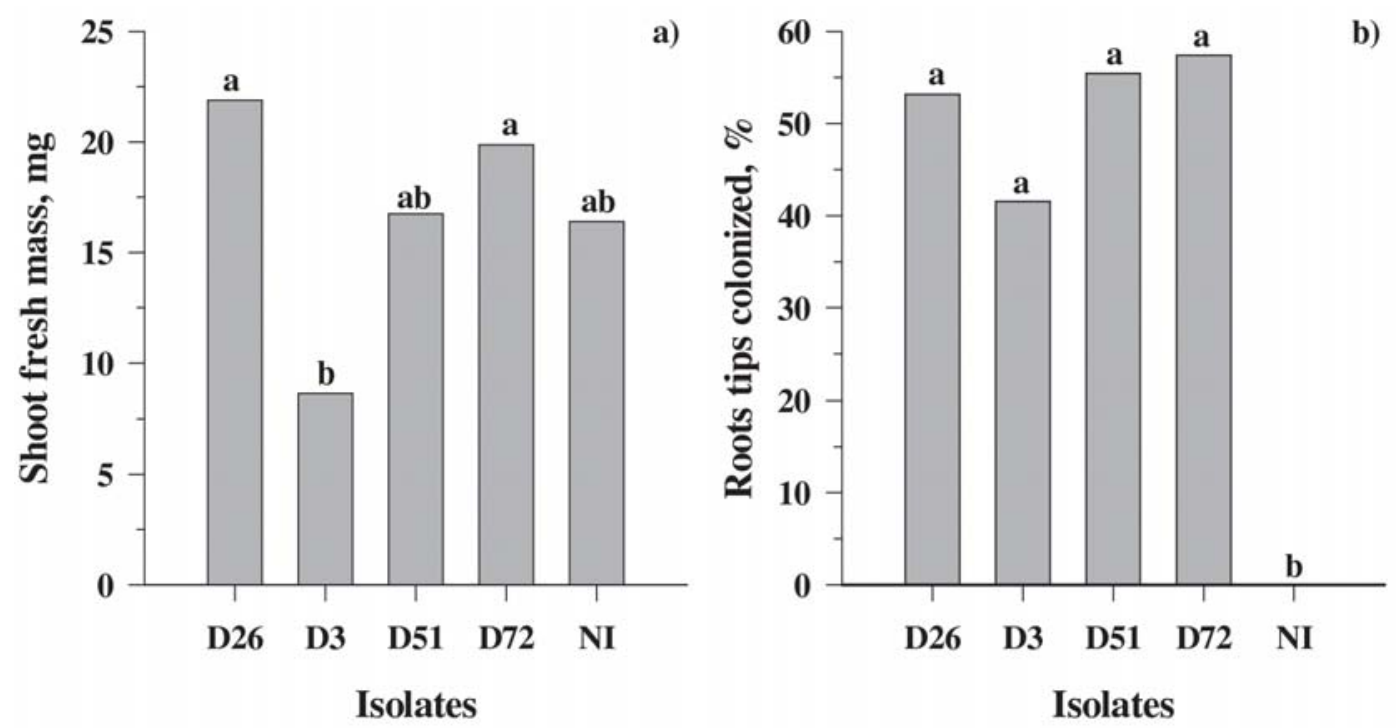

Figure 3 - Shoot fresh weight (a), ectomycorrhizal colonization (b) means of the Eucalyptus urophylla plants inoculated with isolates D3, D26, D51, D72 of Pisolithus sp. and non-inoculated plants (NI), grown in a mixture of peat/ vermiculite added the following P levels: $0.87,1.16$ and $1.72 \mathrm{mg} \mathrm{plant}^{-1}$.

Figura 3 - Massa fresca da parte aérea (a), colonização ectomicorrízica, (b) médias das plantas de Eucalyptus urophylla inoculadas com os isolados D3, D26, D51, D72 de Pisolithus sp. e não-inoculadas (NI), crescidas em uma mistura de turfa/vermiculita adicionada das seguintes doses de P: 0,87, 1,16 e 1,72 mg planta ${ }^{-1}$.

and five of them (D12, SC129, D20, D27, D52) had solely the mantle (Table 1). From the first thirteen isolate, nine (D7, D15, D17, D26, D50, D58, D63, D77, and D81) presented thick fungal mantle.

Among isolates with greater root colonization (D63 $=\mathrm{D} 77=\mathrm{D} 70=\mathrm{D} 81)$, none of them promoted plant growth (height and PFW) and, from the 16 that increased height and PFW, 14 isolates presented non-typical ectomycorrhizae (D4, D5, D6, D10, D12, D13, D14, D20, D23, D27, D46, D52, D61 and SC129). The others obtained less than $29 \%$ of root tip colonization (Figure 4 ). Among isolates that showed some colonization, D12, D15, D20, D27, D52, ITA06 and SC129 raised height and PFW. In addition, D58 and D17 had only effect on PFW.

\section{DISCUSSION}

\subsection{In vitro synthesis of ectomycorrhizae in substrate with different $P$ doses}

The differentiated ability among EMF species (SOUZA et al., 2004; JHA et al., 2008) and Pisolithus sp. isolates (ANDREAZZA et al., 2004) to promote plant growth at varied $\mathrm{P}$ doses was also observed in this study. The height of Eucalyptus grandis plants grown under greenhouse conditions and inoculated with F1-RS isolate of Pisolithus sp. was higher than those with FSE-S of Pt Silv.1, when grown in substrate with $8 \mathrm{mg} \mathrm{kg}^{-1} \mathrm{P}$. Nevertheless, in substrates with $30 \mathrm{mg} \mathrm{kg}^{-1}$ of $\mathrm{P}$, plant heights were equal (ANDREAZZA et al., 2004). The reduction of inoculation beneficial effect that was observed for plants with D26, D51 and D72 isolates compared to the non-inoculated ones with increasing $\mathrm{P}$ doses is reported in literature (SILVA et al., 2003; SOUZA et al., 2004; JHA et al., 2008). In contrast, at the highest dose, D26 has still increased height up to $30^{\text {th }}$ day set against non-inoculated plants. This fact indicates that the $\mathrm{P}$ dose that reduces inoculation effects depends on the isolate type. However, the $\mathrm{P}$ absence effect on SFW is diverged from results observed for eucalypts cultivated in vases (SILVA et al., 2003; ANDREAZZA et al., 2004). This divergence may be due to the low plant growing period and, or low fertility of used substrate.

Fungal mantle and Hartig net presence demonstrate that the studied isolates established a symbiotic relationship with E. urophylla plants. The percentage of colonized root tips (51.9\%) can be considered high since it was higher than the colonization mean (10.2

Revista Árvore, Viçosa-MG, v.39, n.1, p.127-136, 2015 

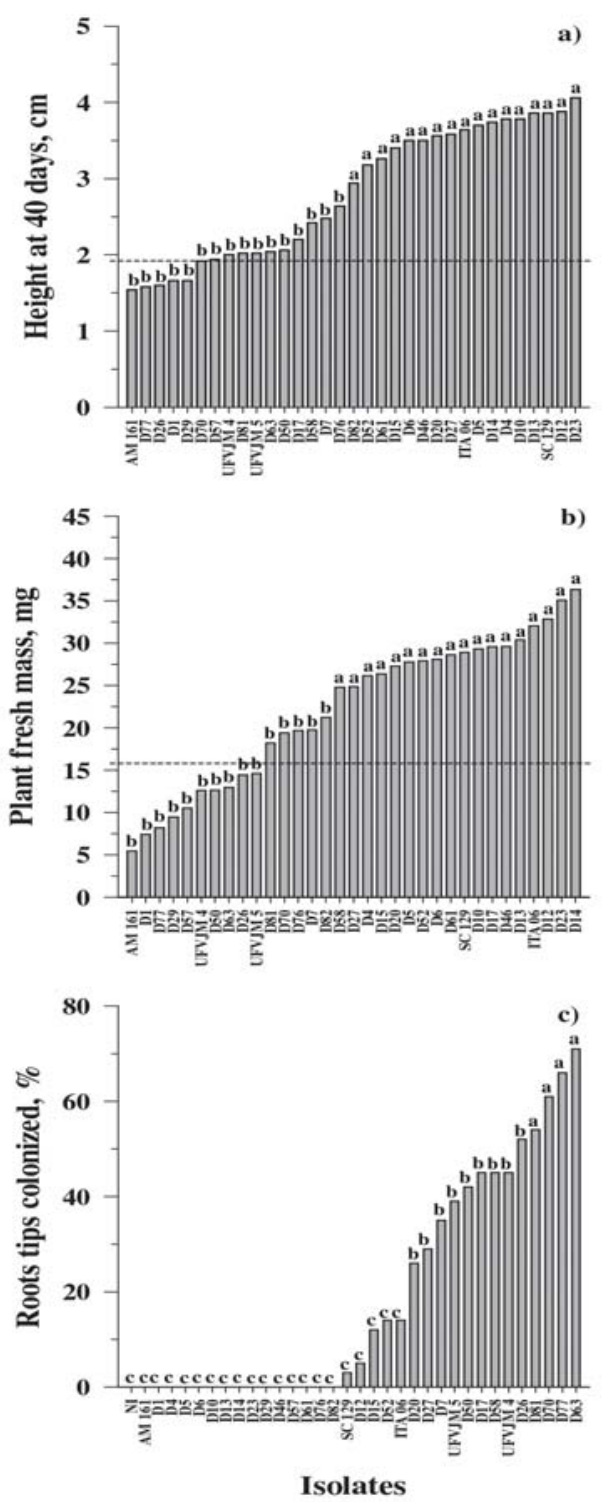

Figure 4 - Height at 40 days (a), plant fresh weight (b) and ectomycorrhizal colonization (c) of Eucalyptus urophylla plants, inoculated with fungal isolates and non-inoculated (-, NI), grown in a mixture of peat/vermiculite added the MNM medium culture. The bars with the same letter do not differ by Scott Knott test at 5\% probability.

Figura 4 - Altura aos 40 dias (a), massa fresca da planta (b) e colonização ectomicorrízica (c) das plantas de Eucalyptus urophylla, inoculadas com isolados fúngicos e não inoculadas (-, NI), crescidas em uma mistura de turfa/vermiculita adicionada ao meio de cultura MNM. As barras com mesma letra não diferem entre si, pelo teste de Scott Knott a $5 \%$ de probabilidade.
Table 1 - Grades awarded to ectomycorrhizal colonization on roots of Eucalyptus urophylla plants inoculated with ectomycorrhizal fungi and grown on a mixture of peat/vermiculite added of MNM culture medium.

Tabela 1 - Notas atribuídas à colonização ectomicorrízica em raízes de plantas de Eucalyptus urophylla inoculadas com isolados de fungos ectomicorrízicos, crescidas em uma mistura de turfa/vermiculita adicionada de meio de cultura MNM.

\begin{tabular}{lccc}
\hline \multirow{2}{*}{ Isolates } & \multicolumn{3}{c}{$\mathrm{P}, \mathrm{mg} \mathrm{plant}^{-1}$} \\
\cline { 2 - 4 } & 0.87 & 1.16 & 1.72 \\
\hline D3 & $++^{1 /}$ & ++ & ++ \\
D26 & ++ & ++ & ++ \\
D51 & ++ & ++ & ++ \\
D72 & ++ & ++ & ++ \\
Non-inoculated & - & - & - \\
\hline
\end{tabular}

$1 /(+)=$ with fungal mantle, $(++)=$ with Hartig net and fungal mantle, $(+++)=$ with Hartig net and thick fungal mantle.

$1 /(+)=$ com manto fúngico, $(++)=$ com rede de Hartig e manto fúngico, $(+++)=$ rede de Hartig e com espesso manto fúngico.

$-36.2 \%$ ) observed for E. globulus and E. grandis (LU et al., 1998; SILVA et al., 2003; ANDREAZZA et al., 2004; SOUZA et al., 2012). Nonetheless, equality among ability of Pisolithus sp. isolates to colonize eucalypts effectively (Figure 3b) and the differences of fungal mantle thickness has not related with the effects on plant growth (Figure 2). Plants inoculated with D3 exhibited similar colonization to the others (Figure 3b). On the other hand, this isolate has generally showed the lowest height and SFW (Figure 2). This may suggest less compatibility between this isolate and the symbiotic plant under the studied conditions.

The lack of interaction between the percentage of colonized root tips and $\mathrm{P}$ doses promoted by Pisolithus sp. isolates (Figure 3) differed from most studies reported in the literature (SOARES et al., 1990; SILVA et al., 2003; ANDREAZZA et al., 2004; SOUZA et al., 2004). This effect is probably because all used $\mathrm{P}$ doses generally near to the ideal range to match root colonization and eucalypts growth (SOUZA et al., 2004). Even the highest dose $\left(1.72 \mathrm{mg}\right.$ plant $\left.^{-1}\right)$ cannot be considered high for seedling production, as in commercial nurseries each plant can receive around $30 \mathrm{mg} P$ throughout the nursery stage as routine, which was the reason of using the higher dose in pre-selection experiment.

Previously, plant height results has particularly demonstrated that D26, D51 and D72 have potential to promote eucalypts growth, and the beneficial effect

Revista Árvore, Viçosa-MG, v.39, n.1, p.127-136, 2015 
of the latter two isolates were restricted to a specific $\mathrm{P}$ dose while the first promoted growth in the three studied doses. This result shows that $\mathrm{P}$ negative effect on ectomycorrhizal symbiosis in eucalyptus can depend on isolate types. This has great importance for EMF selection for inoculation in large commercial eucalypts nurseries, since $\mathrm{P}$ fertilization reduction might imply in increased length of the time that the seedlings stay in nursery, and thus higher costs. The existence of isolates that can colonize and even benefit the seedling growth, even with increased P levels in growth substrate, may facilitate EMF use as biotechnological technique in eucalypts cultivation in Minas Gerais, Brazil. Inoculation advantages of these isolates may be due to greater $\mathrm{P}$ absorption by inoculated plants, but as observed for higher P doses. This gain was minimized after 30 days, what may be caused by some other nutrient growth limitation, despite the noncompliance of any deficiency symptoms. Following this line, further studies aiming to determine the optimal conditions for eucalypts growth and ectomycorrhizal synthesis could contribute to ectomycorrhizal fungus research.

\subsection{In vitro pre-selection of ectomycorrhizal fungi}

EMF ability to promote symbiotic plant growth differs among species and isolate types, as observed in the previous experiment and others (LU et al., 1998; REDDY; SATYANARAYANA, 1998; SOUZA et al., 2012). The proportion of isolates able to form ectomycorrhizal colonies in E. urophylla related to the total studied isolates (54.5\%) (Figure 4c) was lower than the one found in Picea glehnii (70\%) (KASUYA et al., 1996) and the one observed in $E$. grandis (100\%) (COSTA et al., 2010), which was also in vitro culture. These results demonstrate the importance of constant selection of EMF isolates for inoculation in commercial nurseries and point out in vitro synthesis assays to reduce cost in selection programs of ectomycorrhizal fungi. It is still interesting to highlight that different species or even isolates should be recommended at different regions or companies due to environmental conditions or seedling handlings, respectively. Therefore, in vitro synthesis may be useful in previous selection of EMF isolates; however, for mass use, the preselected isolates should be evaluated in commercial nursery conditions, mainly by evaluating seedling survival rate and growth in the field.
The greatest plant height and PFW was observed for those inoculated with Pisolithus sp. isolates with non-typical ectomycorrhizal formation (D4, D5, D6, D10, D13, D14, D23, D46, D61, D76 and D82) (Figure 4), which corroborates with findings in E. globulus inoculated with 18 EMF genera (LU et al., 1998). The explanations about these results are not still clear, although it can be a consequence of fungal activity within root system even without symbiosis establishment at a detectable level (SOUZA et al., 2004). Conversely, for isolates that colonized roots, but have not promoted plant evident gains under the studied conditions, the increased colonization could have proportionated greater demand for photoassimilates, decreasing plant growth during that period. However, the growth gain observed since pre-selection stage may indicate the most promising isolates, the ability to colonize roots should be taken into consideration as an important result for strain pre-selection since mycorrhizae are the ones that will provide significant gains, mainly in adaptation stage after seedling transplantation to the field (MALAJCZUK et al., 1975).

In this sense, the most promising isolates for use in other mycorrhizal control phases were the D15, D17, D58 and ITA06, since, among the 19 isolates that promoted height and PFW gains, they have colonized roots with typical ectomycorrhizal. However, other fungi that have also colonized roots can promote plant growth later, for example, D63 $=\mathrm{D} 77=\mathrm{D} 70=\mathrm{D} 81$ isolates, which had the highest percentage colonized root tips and typical ectomycorrhizal fungi with thick fungal mantle.

\section{CONCLUSIONS}

Root colonization by suitable isolates was high, showing that in vitro cultivation can be used to reduce costs of ectomycorrhizal fungus selection.

Phosphorus rates did not influence shoot fresh weight and root colonization because they were low, but the benefits of inoculation in plant height were dependent on isolate type and $\mathrm{P}$ dose.

Ectomycorrhizal colonization of Eucalyptus urophylla roots and its effects on this plant growth depend on fungal species and isolate.

D15, D17 and D58 isolates of Pisolithus sp. and ITA06 of Pisolithus microcarpus are promising to be used in controlled mycorrhization programs. 


\section{ACKNOWLEDGEMENTS}

We want to thank the Foundation of Research Support of Minas Gerais State (FAPEMIG) and the Foundation of Research and Innovation Support of Santa Catarina State (FAPESC) by this research financial support.

\section{REFERENCES}

ANDREAZZA, R.; ANTONIOLLI, Z. I.; SILVA, R. F.; LONGHI, S. J. Espécies de Pisolithus sp. na produção de mudas de Eucalyptus grandis Hill ex Maiden em solo arenoso. Ciência Florestal, v.14, n.2, p.51-59, 2004.

BARKER, S. J.; TAGU, D.; DELP, G. Regulation of root and fungal morphogenesis in mycorrhizal symbioses. Plant Physiology, v.116, n.4, p.1021-1207, 1998.

BAUMERT, A.; SCHUMANN, B.; PORZEL, A.; SCHMIDT, J.; STRACK, D. Triterpenoids from Pisolithus tinctorius isolates and ectomycorrhizas. Phytochemistry, v.45, n.3, p.499-504, 1997.

BOUGHER, N. L.; GROVE, T. S.; MALAJCZUK, N. Growth and phosphorus acquisition of karri (Eucalyptus diversicolor B. Muell.) seedlings inoculated with ectomycorrhizal fungi in relation to phosphorus supply. New Phytologist, v.114, n.1, p.77-85, 1990.

BRUNDRET, M.; BOUGHER, N. L.; DELL, B.; GROVE, T.; MALAJCZUK, N. Working with mycorrhizas in forestry an agriculture. Canberra: Australian Centre for International Agricultural Research, 1996. 374p.

COSTA, M. D.; CAMPOS, A. N. R.; SANTOS, M. L. S.; BORGES, A. C. In vitro ectomycorrhiza formation by monokaryotic and dikaryotic isolates of Pisolithus microcarpus in Eucalyptus grandis. Revista Árvore, v.34, n.3, p.377-387, 2010.

DiGhtON, J.; POSKITT, J. M.; BROWN, T. K. Phosphate influx into ectomycorrhizal and saprotrophic fungal hyphae in relation to phosphate supply: a potencial method for selection of efficient mycorrhizal species.

Mycological Research, v.97, n.3, p.355-358, 1993.

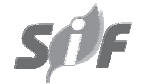

GARBAYE, J. Utilisation des mycorhizes en sylvicuture. In: STRULLU, D.G. (Ed). Les mycorhizes des arbres et plantes cultivées. Paris: Lavoisier, 1990. p.197-248.

GRAZZIOTTI, P. H.; SIQUEIRA, J. O.; MOREIRA, F. M. S. Espécies arbóreas e ectomicorrizas em relação ao excesso de metais pesados. Tópicos em Ciência do Solo, v.5, p.55-105, 2003.

JHA, B. N.; SHARMA, G. H.; SHUKLA, A. K. Effect of ectomycorrhizal development on growth in pines seedlings. Journal of Plant Sciences, v.3, n.1, p.77-84, 2008.

KASUYA, M. C. M.; IGARASHI T. In vitro ectomycorrhizal formation in Picea glehnii seedlings. Mycorrhiza, v.6, n.5, p.451-454, 1996.

LU, X.; MALAJCZUK, N.; DELL, B. Mycorrhiza formation and growth of Eucalyptus globulus seedlings inoculated with spores of various ectomycorrhizal fungi. Mycorrhiza, v.8, n.2, p.81-86, 1998.

MARX, D. H. The influence of ectotrophic mycorrhizal fungi on the resistance of pine roots to pathogenic infections. I. Antagonism of mycorrhizal fungi to root pathogenic fungi and soil bacteria. Phytopathology, v.59, n.2, p.153$163,1969$.

MALAJCZUK, N.; McCOMB, A. J.; LONERAGAN, J. F. Phosphorus uptake and growth of mycorrhizal and uninfected seedling of Eucalyptus calophylla. Australian Juornal Botany, v.23, n.2, p.231-238, 1975.

POZO, M. J.; AZCON-AGUILAR, C. Unraveling mycorrhiza-induced resistance. Current Opinion in Plant Biology, v.10, n.4, p.393398, 2007.

QUORESHI, A. M.; KHASA, D. P. Effectiveness of mycorrhizal inoculation in the nursery on root colonization, growth, and nutrient uptake of aspen and balsam poplar. Biomass and Bioenergy, v.32, n.5, p.381-391, 2008.

REDDY, M. S.; SATYANARAYANA, T. Inoculation of micropropagated plantlets of Eucalyptus tereticornis with ectomycorrhizal fungi. New Forests, v.16, n.3, p.273-279, 1998.

Revista Árvore, Viçosa-MG, v.39, n.1, p.127-136, 2015 
SAWYER, N. A.; CHAMBERS, S. M.; CAIRNEY, J. W. G. Utilisation of inorganic and organic phosphorus sources by isolates of Amanita muscaria and Amanita species native to temperate eastern Australia. Australian Journal of Botany, v.51, n.2, p.151-158, 2003.

SILVA, R. F.; ANTONIOLLI, Z. I.; ANDREAZZA, R.; LONGHI, S. J. Fungos ectomicorrízicos no desenvolvimento de mudas de Eucalyptus grandis Hill ex Maiden. Biosciense Journal, v.19, n.3, p.9-17, 2003.

SOARES, I.; BORGES, A. C.; BARROS, N. F.; BELLEI, M. M. Níveis de fósforo na formação de ectomicorrizas em mudas de eucalipto. Revista
Brasileira de Ciência do Solo, v.14, n.3 p.327332, 1990.

SOUZA, L. A. B.; SILVA FILHO, G. N.;

OLIVEIRA, V. L. Eficiência de fungos ectomicorrízicos na absorção de fósforo e na promoção do crescimento de eucalipto.

Pesquisa Agropecuária Brasileira, v.39, n.4, p.349-355, 2004.

SOUZA, E. L.; ANTONIOLLI, Z. I.; MACHADO, R. G.; ECKHARDT, D. P.; DAHMER, S. F. B.; SCHIRMER, G. K. Efeito da inoculação com isolados de fungos ectomicorrízicos sobre o desenvolvimento de mudas de Eucalyptus grandis Hill ex Maiden. Ciência Florestal, v.22, n.2, p.251-261, 2012. 